\title{
Cross clade reactive plasma anti-V3 antibodies in human immunodeficiency virus type- 1 infected individuals develop with time
}

\author{
Raiees Andrabi', Manju Bala ${ }^{2}$, Kalpana Luthra ${ }^{1 *}$ \\ From First International Science Symposium on HIV and Infectious Diseases (HIV SCIENCE 2012) \\ Chennai, India. 20-22 January 2012
}

\section{Background}

Subtype-C alone accounts for approximately $50 \%$ of global and more than $95 \%$ human immunodeficiency virus1 (HIV-1) infection in India. Identification of antigenic epitopes that induce antibodies with cross-clade activity will be crucial to address the HIV-1 viral diversity.

\section{Methods}

80 HIV-1 infected drug naive patients were recruited for this study. The study was approved by the institute ethics committee and informed consent was obtained from all the participants. The relative binding of anti-V3 polyclonal plasma antibodies to 35 mer consensus-B and C V3 peptides was done by ELISA binding assay. Statistical analysis was performed by Graphpad Prism 5 .

\section{Results}

Assessment of the relative binding revealed that $86 \%$ $(69 / 80)$ and $99 \%(79 / 80)$ of the plasma were able to reach an IC50 binding titer with V3B peptide and V3C peptides respectively; with substantially low antibody titers that bind to V3B than V3C (mean IC50, $\mathrm{V} 3 \mathrm{~B}=2736$ versus $\mathrm{V} 3 \mathrm{C}=12612)(\mathrm{p}<0.0001)$. The finding suggests that although majority of the antibodies were subtype specific, a good proportion of cross reactive anti-V3 antibodies also exist in these plasma ( mean $=23 \%$ range $=0.11-97 \%$ ). We observed a positive correlation between percent cross reactive anti-V3 antibodies and days from first diagnosis $(\mathrm{p}=0.008)$ while no such association was found with other clinical and immunological parameters like plasma viral load

\footnotetext{
* Correspondence: kalpanaluthra@gmail.com

${ }^{1}$ Department of Biochemistry, All India Institute of Medical Sciences, New Delhi, India
}

Full list of author information is available at the end of the article $(\mathrm{p}=0.24), \mathrm{CD} 4$ count $(\mathrm{p}=0.34)$ and total plasma IgG levels $(\mathrm{p}=0.45)$.

\section{Conclusions}

This is the first study to demonstrate the presence of cross-clade reactive anti-V3 antibodies and their association with time in the plasma of HIV-1 infected Asian Indians from north India.

\section{Author details}

${ }^{1}$ Department of Biochemistry, All India Institute of Medical Sciences, New Delhi, India. ${ }^{2}$ Regional STD Teaching Training \& Research Centre, Safdarjang Hospital, New Delhi, India.

Published: 4 May 2012

\section{doi:10.1186/1471-2334-12-S1-P24}

Cite this article as: Andrabi et al:: Cross clade reactive plasma anti-V3 antibodies in human immunodeficiency virus type- 1 infected individuals develop with time. BMC Infectious Diseases 2012 12(Suppl 1): P24.

Submit your next manuscript to BioMed Central and take full advantage of:

- Convenient online submission

- Thorough peer review

- No space constraints or color figure charges

- Immediate publication on acceptance

- Inclusion in PubMed, CAS, Scopus and Google Scholar

- Research which is freely available for redistribution

Submit your manuscript at www.biomedcentral.com/submit
() Biomed Central

\section{() Biomed Central}

